ScIDice

\section{International Journal of Dentistry and Oral Science (IJDOS) \\ ISSN: $2377-8075$}

\title{
Surgical Alternative in Sinus Lift Reoperation
}

Costa $\mathrm{BE}^{1 *}$, Grolli Klein $\mathrm{GB}^{2}$, Siqueira $\mathrm{L}^{2}$, de Lima Romeiro R ${ }^{3}$, Ribeiro-Junior PD ${ }^{4}$

${ }^{1}$ Postgraduate Student. Department of Oral and Maxillofacial Surgery, USC- Sagrado Coração University, Bauru, São Paulo, Brazil.

${ }^{2}$ Associate Professor, Department of Implants, CEOSP-Nanotec, Chapecó, Santa Catarina, Brazil.

${ }^{3}$ Associate Professor, Department of Surgery and Radiology, School of Dentistry, Pindamonhangaba University, Pindamonhangaba, SP, Brazil.

${ }^{4}$ Full Professor and Chairman, Department of Oral and Maxillofacial Surgery, USC- Sagrado Coração University, Bauru, São Paulo, Brazil.

\section{Abstract}

The increasing use of osseointegrated implants requires special attention to overcome limitations in bone tissue. In maxillary posterior region, sinus pneumatization reduces bone availability for implants insertion. Membrane perforation is commonly observed during sinus lift procedure, when trying to achieve bone volume. Through a case where the implant was removed from inside the maxillary sinus patient, causing extreme membrane and bone damage. An alternative treatment using the periosteum as membrane is described.

Keywords: Dental Implants; Maxillary Sinus; Complications; Membrane Perforation.

\section{Introduction}

The increasing use of osseintegrated implants [1] also requires special attention to overcome limitations in bone tissue. In maxillary posterior region, sinus pneumatization is the most common complication that reduces bone availability for implants insertion $[2,3]$.

The technique of sinus lift described by Tatum [4] and Boyne and James [5] is the most successful approach for bone regeneration in atrophic maxilla. According to this technique, an opening at lateral sinus wall is created to displace the Schneiderian membrane in order to fill the space in sinus floor with a graft material [6]. Thus, the integrity of Schneiderian membrane is essential for sinus lift success.

However, membrane perforation is commonly observed during this procedure [7], ranging from 20 to $60 \%$ [8]. As a consequence, some professionals avoid reconstructive techniques using short and thin implants [9]. Nevertheless, the poor bone density in maxillary posterior region may affect osseointegration or cause implant displacement into maxillary sinus [10].
Although the Caldwell-Luc technique [11] has been indicated to remove foreign bodies presented into the maxillary sinus, this procedure causes extensive damage in the Schneiderian membrane and compromises future bone regeneration [12].

Thus, the aim of this study was to report a sinus lift technique after extensive damage in Schneiderian membrane resulting from removal of implant in maxillary sinus using the Caldwell-Luc technique.

\section{Case Report}

The patient reported pain and swelling in the region from teeth 12 to 14 two weeks after a surgical procedure for implants insertion.

Clinical exam revealed reddish gingiva and pain to palpation without pus. The periapical radiograph showed the presence of three implants and the implant inserted in the region of 13 moved to the maxillary sinus. The remaining implants exhibited poor bone support that could affect osseointegration (Figure 1). Thus, the removal of all implants was indicated.

*Corresponding Author:

Beethoven Estevão Costa,

Postgraduate Student, Department of Dental, Oral and Maxillofacial Surgery, USC- Sagrado Coração University, Bauru, São Paulo, Brazil.

Tel: 5514 3104-9065 / 5537 99992-7350

E-mail: beethovencosta@gmail.com

Received: November 07, 2017

Accepted: November 27, 2017

Published: November 28, 2017

Citation: Costa BE, Grolli Klein GB, Siqueira L, de Lima Romeiro R, Ribeiro-Junior PD. Surgical Alternative in Sinus Lift Reoperation. Int J Dentistry Oral Sci. 2017;4(11):552556. doi: http://dx.doi.org/10.19070/2377-8075-17000109

Copyright: Estevão Costa $\mathbf{B}^{\circ}$ 2017. This is an open-access article distributed under the terms of the Creative Commons Attribution License, which permits unrestricted use, distribution and reproduction in any medium, provided the original author and source are credited. 
The procedure was conducted in ambulatory environment under local anesthesia with $2 \%$ mepivacaine hydrochloride with 1:100,000 adrenaline. The Caldwell-Luc technique was used to access the maxillary sinus. The osteotomy in the sinus lateral wall was conducted with a spherical bur (\#8) in low-speed handpiece and electric surgical motor. The implant was removed under abundant irrigation with saline and aspiration. The remaining implants were removed using reverse torque.

The procedure caused extensive damage in the sinus lateral wall and Schneiderian membrane, preventing any immediate regeneration or rehabilitation.

After 8 months, another clinical exam was conducted to plan the procedures of bone regeneration for implants insertion.

Two planning treatments were established based on tomography and prototyping (Figure 2). One alternative was the fixation of bone blocks into the maxillary sinus while the other approach suggested the use of particulate bone using the periosteum as a membrane based on a technique with divided flap in the defect area. The treatment planning was selected at the moment of the surgery since bonding between periosteum and Schneiderian membrane could not be detected through the complementary exams. Iliac crest was used as donor area.

The second surgical step was conducted in the hospital under general anesthesia associated with local anesthesia with $2 \%$ mepivacaine hydrochloride with 1:100,000 adrenaline. The treatment alternative using particulate bone after displacement of the Schneiderian membrane was selected (Figure $3 \mathrm{a} / \mathrm{b}$ ).
Additional radiographic exams taken six months after grafting revealed enough bone volume for implants insertion (Figure 4). Another surgery was indicated for fixation of 3 implants. The procedure was conducted in ambulatory environment under local anesthesia with $2 \%$ mepivacaine hydrochloride with 1:100,000 adrenaline. External hexagon cylindrical implants (Titanium Fix) were inserted in the region of teeth 12 (3.75 mm x $13 \mathrm{~mm}), 13$ $(3.75 \mathrm{~mm} \times 10 \mathrm{~mm})$ and $14(3.75 \mathrm{~mm} \times 10 \mathrm{~mm})$. All implants exhibited appropriate initial stability ranging from 30 to $50 \mathrm{~N}$ (Figure $5 \mathrm{a} / \mathrm{b}$ ).

After all surgical procedures, it was administered amoxicillin 875 $\mathrm{mg}$ twice a day for 7 days, nimesulide $100 \mathrm{mg}$ twice a day for 3 days, paracetamol $750 \mathrm{mg}$ four times a day for 5 days, and mouth washing with $0.12 \%$ chlorhexidine gluconate three times a day for 10 days.

After 6 months for osseointegration, the implants were reopened to place regular healing abutments with height ranging from 3 to $4 \mathrm{~mm}$. After gingival repair, open-tray impression was taken and 3 porcelain-fused-to-metal crowns were attached (Figure 6).

\section{Discussion}

The displacement of implants into maxillary sinus is a frequent complication reported as a consequence of increasing insertion of implants in maxillary posterior region [13].

In addition to iatrogenic procedures, Galindo P. et al., suggested 3 other reasons for implant migration into sinus: 1-alteration of intra-sinus pressure, 2-autoimmune reactions against implants caus-

Figure 1. Initial X-Ray to Look Previous Implants. Implants in 12 and 14 Teeth Region with Little Bone Insertion and in 13 Tooth Region the Implant was Inside the Maxillary Sinus.

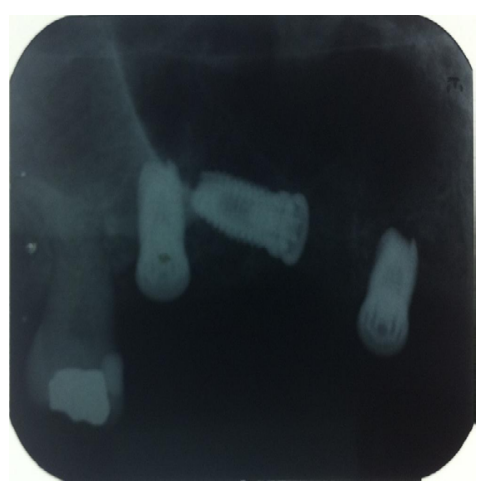

Figure 2. Cone Bean CT after Implants Removal Showing all Damage Caused to Lateral Bone Wall and Schnederian Membrane, During the Implants Removal.

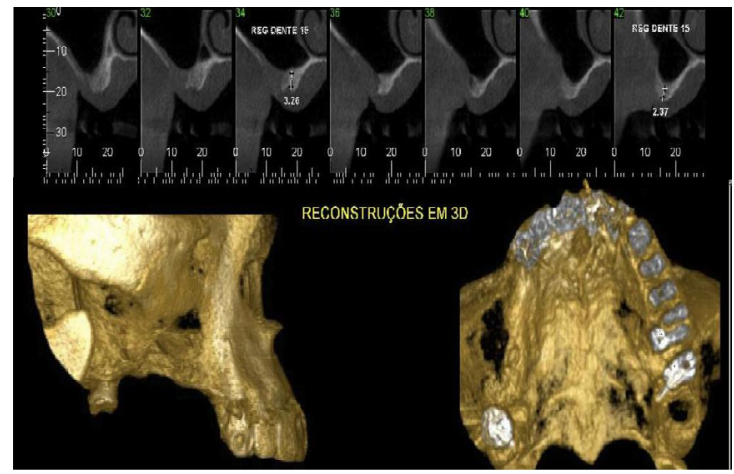


Figure 3a/b. Sinus Approach - \# Schneiderian Membrane * Periosteum. After Flap Elevation and Divided, is Possible to See the Difference Between Both Structures. The Sinus Lift Technic was Used, and the Sinus was Filled with Particulate Autogenous Bone Graft.

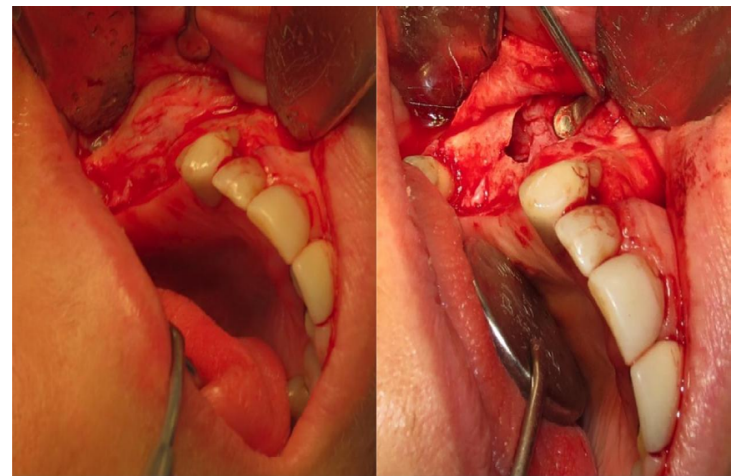

Figure 4. Cone Bean CT after Sinus Graft Showing the Great Bone High Obtained, Making Possible the use of Traditional Dental Implants.

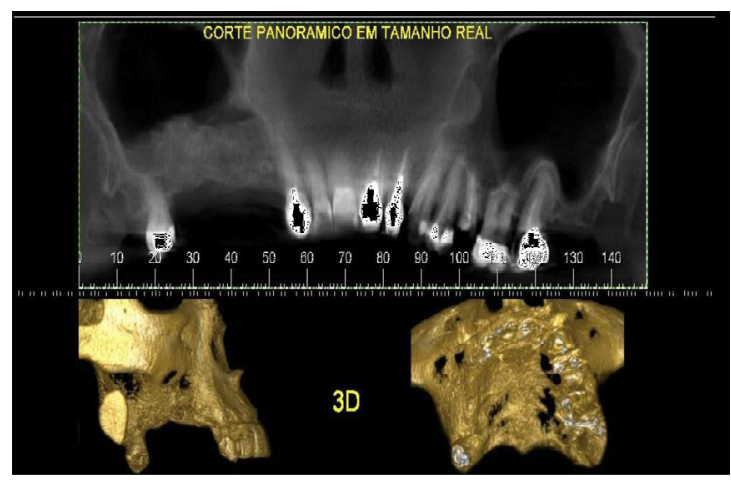

Figure 5 a/b. Implants Placement in the 12, 13, 14 Teeth Region by Tradicinonal Technic using External Hexagon Cylindrical Implants, with Good Primary Stability.

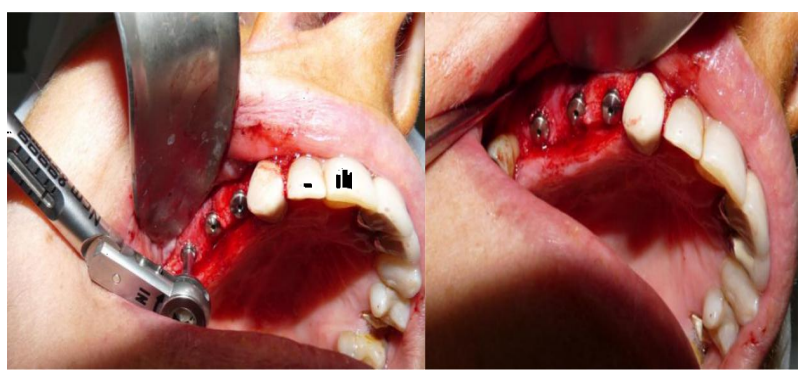

Figure 6. After Osseointegration Time, 6 months, the Implants was Restored using Metallic - Ceramic Crowns.

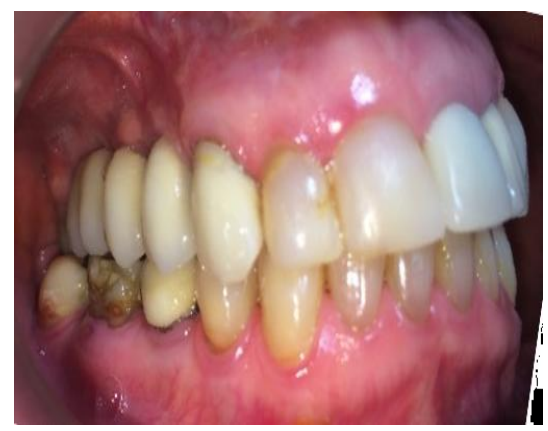

ing bone destruction and loss of osseointegration, and 3-bone resorption as a result of occlusal trauma [14].

Foreign bodies into sinus cavity cause sinus inflammation due to interruption of mucous-ciliary mobility and/or tissue reaction [15] that can cause aspergillosis [16]. Scorticati MC et al., reported cases of intense headache caused by foreign bodies presented into the maxillary sinus [17]. Thus, any object inside the sinus must be removed even under asymptomatic condition [18].

Several techniques have been suggested for removal of implants into the sinus, such as Caldwell-Luc intra-oral access, trans-nasal endoscopy [19] or an association of both methods [20]. The selection of each approach depends on proper indication consider- 
ing the possible damage and further insertion of dental implants.

Treatments using endoscopes preserve the sinus epithelium and unstop the ostium obliterated by chronic inflammation [21]. However, this alternative is not commonly indicated because it requires specific equipment and training and also extensive opening for sinus manipulation and object removal [22].

The intra-oral approach provides direct visualization, easy access and appropriate opening for removal of foreign bodies. On the other hand, it may cause damage to infra-orbital nerve, retraction of cheek soft tissue, buccal-sinus fistula, and extensive damage in the sinus lateral wall and Schneiderian membrane [23, 24].

The treatment of sinus membrane perforation is challenging. For Testori et al., [25] three alternatives can be taken: 1-use of collagenous membrane for obliteration, 2-natural membrane healing, and 3-use of block without membrane repair.

Considering that the use of membranes is not appropriate after extensive damage in the Schneiderian membrane, the other alternatives can be indicated [26, 27].

For natural membrane healing, 3 to 4 weeks are required for repair without interposition of any material between the Schneiderian membrane and alveolar mucosa for proper bonding [28].

According to the repair protocol suggested by Fugazzotto and Valssis for defects class V (i.e. sinus lift in areas with Schneiderian membrane perforation [29]), the treatment should divide the buccal flap in order to provide sealing with the periosteum, conventional membrane lift and insertion of particulate material.

In a different scenario, bone regeneration can be achieved through complete curettage of the Schneiderian membrane and further fixation of bone blocks in the sinus medial wall [30].

The iliac crest was selected as the donor area because it is an autogenous material, a gold standard for bone regeneration, and it also provides a 3D structure for adaptation and fixation of bone blocks. In addition, the iliac crest bone can be inserted as a particulate material in case of membrane displacement.

\section{Conclusion}

This study demonstrated that implant-supported rehabilitation can be conducted through bone regeneration in maxillary sinus even after extensive Schneiderian membrane perforation.

The technique can be indicated as a safe and predictable alternative to provide appropriate clinical results of bone repair.

\section{References}

[1]. Exposito M, Murray-Curtis L, Grusovin MG, Coulthard P, Worthingtom HV. Interventions for replacing missing teeth: diferente types of dental implants. Cochrane Database Syst Rev. 2007 Oct 17;(4):CD003815. PubMed PMID: 17943800.

[2]. Chiapasco M, Zaniboni M, Boisco M. Augmentation procedures for the rehabilitation os deficiente endentulous ridges with oral implants. Clin Oral Implants Res. 2006 Oct;17 Suppl 2:136-159. PubMed PMID: 16968389.

[3]. Chiapasco M, Zaniboni M, Rimondini L. Dental implants placed in grafted maxillary sinuses. A retrospective analisis of clinical outcome occording to the inicial clinical situation and proposal os defect classification. Clin Oral Implants Res. 2008 Apr;19(4):416-428. PubMed PMID: 18266875.

[4]. Tatum OH. Maxillary and sinus implant reconstruction. Dent Clin North Am. 1986 Apr;30(2):207-229. PubMed PMID:3516798.

[5]. Boyne P, James RA. Grafting of the maxillary sinus floor with autogenous narrow and bone. J Oral Maxillofac Surg. 1980 Aug;38(8):613-616. PubMed PMID: 6993637.

[6]. Jensen OT, Shulman LB, Block MS, Iacono VJ. Report of the sinus consensus conference of 1996. Int J Oral Maxillofac Implants. 1998;13 Suppl:11-45. PubMed PMID: 9715571.

[7]. Cho SC, Wallace SS, Froum SJ, Tarnow DP. Influence of anatomy on Scheneiderian membrane perforations during sinus elevation surgery: Three dimensional analysis. Pract Proced Aesthet Dent. 2001 Mar;13(2):160-163. PubMed PMID: 11315435.

[8]. Ardekian L, Oved-Peleg E, Mactei EE, Peled M. The clinical significance of sinus membrane perforation during augmentation of the maxillary sinus. J Oral Maxillofac Surg. 2006 Feb;64(2):277-282. PubMed PMID:16413901.

[9]. Arlin ML. Short dental implants as a treatment option: results from an observational study in a single private practice. Int J Oral Maxillofac Implants. 2006 Oct;21(5):769-777. PubMed PMID: 17066639.

[10]. Haben CM, Balys R, Frenkiel S. Dental implant migration into the ethmoid sinus. J Otolaryngol. 2003 Oct;32(5):342-344. PubMed PMID:14974869.

[11]. Caldwell G. Disease of the accessory sinuses of the nose anda $\mathrm{n}$ improved method to treatment for suppution of th maxillary antrum. NY Med J. 1893:58:526-530.

[12]. Biglioli F, Goisis M. Acess to maxillary sinus using a bone flap on mucosal pedicle: Preliminary report. J Oral Maxillofac Sug. 2002 Aug;30(4):155159. PubMed PMID: 12231208

[13]. Chiapasco M, Felisati G, Maccari A, Borloni R, Gatti F, Di Leo F. The management of complications following displacement of oral implants in the paranasal sinuses: a multicenter clinical report and proposed treatment protocols. Int J Oral Maxillofac Surg. 2009 Dec;38(12):1273-1278. PubMed PMID: 19781911.

[14]. Galindo P, Sánchez-Fernández E, Avila G, Cutando A, Fernandez JE. Migration of implants into de maxilary sinus: Two clinical cases. Int J Oral Maxillofac Implants. 2005 Apr;20:291-295. PubMed PMID: 15839124.

[15]. Kluppel LE, Santos SE, Olate S, Freire Filho FW, Moreira RW, de Moraes M. Implant migrantion into maxillary sinus: description of two asymptomatic cases. Oral Maxillofac Surg. 2010 Mar;14(1):63-66. PubMed PMID: 19865837.

[16]. Ueda M, Kaneda T. Maxillary sinusites caused by dental implants: Reporto f two cases. J Oral Maxillofac Surg. 1992 Mar;50(3):285-287. PubMed PMID: 1542071.

[17]. Scorticati MC, Raina G, Fedetico M. Cluster-like headache associated to a foreign body from the maxillary sinus. Neurology. 2002 Aug 27;59(4643):643-644.

[18]. Raghoebar GM, Vissink A. Treatment for endosseous implant migrated into the maxillary sinus not causing maxillary sinusites: Case report. Int J Oral Maxillofac Implants. 2003 Oct;18(5):745-749. PubMed PMID: 14579964.

[19]. Kluppel LE, Santos SE, Olate S. Implant migration into maxillary sinus: description of two asymptomatic cases. Oral Maxillofac Surg. 2010 Mar;14(1):63-66. PubMed PMID: 19865837.

[20]. Kim JW, Lee CH, Kwon TK, Kim DK. Endoscopic Removal of a dental implant throuth a middle meatal antrostomy. Br J Oral Maxillofac Surg. 2007 Jul;45(5):408-409. PubMed PMID: 16431000.

[21]. Scarano A, Perrotti V, Carinci F, Shibli JA. Removal of a migrated dental implant from the maxillary sinus after 7 years: A case report. Oral Maxillofac Surg. 2011 Dec;15(4):239-243. PubMed PMID: 20676909.

[22]. Kitamura A. Removal of a migrated dental implant from a maxillary sinus by transnasal endoscopy. Br J Oral Maxillofac Surg. 2007 Jul;45(5):410-411. PubMed PMID: 16457911.

[23]. Nakamura N, Mitsuyasu T, Ohishi M. Endoscopic removal of a dental implant displaced into th maxillary sinus. Int Oral Maxillofac Surg. 2004 Mar;33(2):195-197. PubMed PMID: 15050077.

[24]. Lubbe DE, Anituth S, Peck T, Liebenberg S. Endoscopic transnasal removal of migrated dental implants. Br Dent J. 2008 Apr;204(8):435-436. PuBmed PMID: 18438372. PubMed PMID: 1849872.

[25]. Anzalone J, Vastardis S. Oroantral communication as an osteotome sinus elevation complication. J Oral Implantol. 2010;36(3):231-237. PubMed PMID: 20553178.

[26]. Testori T, Wallace SS, Del Fabbro M, Taschieri S, Trisi P, Capelli M, et al. Repair of large sinus membrane perforations using stabilized collagen barrier membranes: surgical techniques with histologic and radiographic evidence of success. Int J Periodontics Restorative Dent. 2008 Feb;28(1):9-17. PubMed PMID: 18351198.

[27]. Tsodoulos S, Krabouta I, Voulgaropoulou M, Georgiou C. Atraumatic removal of an asymptomatic migrated dental implant into de maxilar sinus: A 
case report. J Oral Implantology. 2012 Apr;38(2):189-193. PubMed PMID: 20822468.

[28]. Sendyk WR, Sendyk CL, Jahn RS. Bone grafts for reconstruction of the posterior atrophic maxilla in Dear MRN, Fan YL. Osseointegrated Implants: Innovating Solutions. São Paulo: Medical Arts; 2004.

[29]. Vlassis JM, Fugazzotto PA. A classification system for sinus membrane per- forations during augmentation procedures with options for repair. J Periodontol. 1999 Jun;70(6):692-699. PubMed PMID: 10397526.

[30]. van den Bergh JP, ten Bruggenkate CM, Disch FJ, Tuinzing DB. Anatomical aspects of sinus floor elevations. Clin Oral Implants Res. 2000 Jun;11(3):256-265. PubMed PMID: 11168217. 